\title{
TEXT MINING MENGGUNAKAN GENERATE ASSOCIATION RULE WITH WEIGHT (GARW) ALGORITHM UNTUK ANALISIS TEKS WEB CRAWLER
}

\author{
Zulkifli Arsyad \\ Politeknik Negeri Bandung \\ zulkifli.arsyad@jtk.polban.ac.id
}

\begin{abstract}
Text mining is widely used to find hidden patterns and information in a large number of semi and unstructured texts. Text mining extracts interesting patterns to explore knowledge from textual data sources. Association rule extraction GARW (Generating Association Rule using Weighting Scheme) can be used to find knowledge from a collection of web content without having to read all the web content manually from the many search results of crawlers. The GARW algorithm is a development of a priori to produce relevant association rules. From the results of this knowledge discovery can facilitate netizens users in finding relevant information from search keywords without having to review one by one web content generated from search engine searches.
\end{abstract}

Keyword: Text Mining, Association Rule, GARW,Web Crawler.

\section{ABSTRAK}

Text mining secara luas digunakan untuk menemukan pola yang tersembunyi dan informasi dalam sejumlah besar teks semi dan tidak terstruktur. Text mining mengekstrak pola yang menarik untuk mengeksplorasi pengetahuan dari sumber data tekstual. Association rule extraction GARW (Generating Association Rule using Weighting Scheme) dapat digunakan untuk menemukan pengetahuan dari kumpulan konten web tanpa harus membaca semua konten web secara manual dari sekian banyaknya hasil pencarian web crawler search engine. Algoritma GARW merupakan pengembangan dari apriori untuk menghasilkan aturan asosiasi yang relevan. Dari hasil penemuan pengetahuan ini dapat memudahkan pengguna netizen dalam menemukan informasi yang relevan dari kata kunci pencarian tanpa harus mereview satu persatu konten web yang dihasilkan dari pencarian search engine.

Kata Kunci: Text Mining, Association Rule, GARW, Web Crawler.

\section{PENDAHULUAN}

Proses menganalisa data dan informasi dari internet, menemukan rangkuman informasi yang tepat dari berbagai halaman web dengan teks yang semi terstruktur serta tidak terstruktur saat ini dilakukan secara manual, kesempatan untuk mengabaikan data yang tidak terstruktur merupakan hal yang penting dalam dunia kompetitif saat ini, menurut survey IDC, data tidak terstuktur menempati $80 \%$ dibandingkan dengan hanya $20 \%$ untuk data terstruktur. Hal ini menggambarkan bahwa diperlukan waktu untuk memilah data yang diterima dari $80 \%$ data yang tidak terstruktur tersebut.

Teks mining merupakan teknik untuk menganalisa sejumlah besar teks bahasa alami, dan mendeteksi pola leksikal untuk mengekstrak informasi yang berguna, text mining ini digunakan untuk menemukan informasi yang menarik dari basis data yang sangat besar ( $\mathrm{R} \&$ Vijayarani, 2016).Secara konsepnya teks mining merupakan teknik yang digunakan untuk menangani permasalahan klasifikasi, kluster, ekstraksi informasi dan pencarian informasi (R. Talib, 2016). Text mining secara luas digunakan untuk menemukan pola yang tersembunyi dan informasi dalam sejumlah besar teks semi serta tidak terstruktur (Naithani, 2016). Hal ini menjadi open issue yang menarik untuk di analisis bagaimana melakukan ekstraksi informasi 
dari data yang tidak terstruktur pada web dari data yang tersebar di berbagai server di seluruh dunia.

Text mining atau penemuan pengetahuan merupakan sub proses dari data mining, yang secara luas digunakan untuk menemukan pola yang tersembunyi dan informasi dalam sejumlah besar teks tidak terstruktur (Naithani, 2016). Text mining mengekstrak pola yang menarik untuk mengeksplorasi pengetahuan dari sumber data tekstual, sumber yang menjadi kajian peneliti ini bersumber dari web yang menghasilkan banyak sekali konten tekstual yang beraneka ragam strukturnya (R. Talib, 2016). Text mining merupakan pendekatan multi-disiplin atau pendekatan yang berdasarkan pada pencarian informasi, data mining, machine learning, statistik, dan komputasi linguistik (R. Talib, 2016).

Dalam text mining terdapat tahapan-tahapan yang umumnya dilakukan (R \& Vijayarani, 2016).

1. Mengkonversi data yang tidak terstruktur menjadi terstuktur,

2. Mengidentifikasi pola dari struktur data,

3. Menganalisis pola menggunakan algoritma text mining,

4. Mengekstrak informasi yang bermanfaat dari text.

Untuk menjalankan setiap tahapan dalam teks mining, terdapat teknik atau pendekatan yang dapat dipilih yang disesuaikan dengan domain yang akan diteliti, berikut ini gambar interaksi text mining antar pendekatan (R. Talib, 2016).

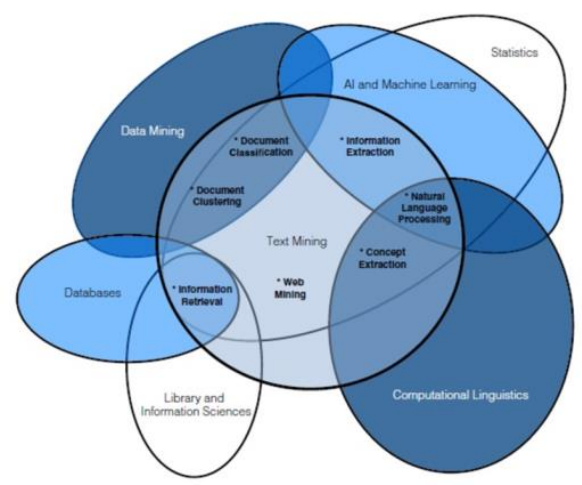

\section{Gambar 1. Diagram interaksi text mining antar pendekatan}

Pada diagram tersebut terlihat keterkaitan antar pendekatan yang terdapat pada text mining ini, peneliti menentukan web mining yang menjadi issue yang cukup menarik untuk dikaji lebih jauh mengingat, konten yang sangat banyak dari web yang dihasilkan serta struktur yang berbeda-beda, dan memiliki interaksi dengan beberapa pendekatan dalam text mining.

Dalam pencarian kata kunci pada search engine, terdapat banyak sekali tautan halaman web yang dimunculkan pada search engine. Dari laman yang ditampilkan pada hasil pencarian dapat kita lakukan analisis untuk menemukan rangkuman informasi yang dibutuhkan dari masing-masing laman yang di tampilkan berdasarkan pencarian kata kunci. Konsep tersebut menjadi menarik jika dilengkapi dengan association rule extraction yang sangat berguna untuk menemukan pengetahuan dari kumpulan dokumen tanpa membaca semua dokumen secara manual (Kulkarni, 2016). Dalam association rule ini dihasilkan dari aturan yang memenuhi kriteria seperti support, confidence, dan nilai TF-IDF kata kunci. Algoritma ini disebut sebagai GARW (Generating Association Rule using Weighting Scheme). Algoritma GARW beroperasi dengan cara yang sama seperti algoritma apriori akan tetapi ditambahkan dengan beberapa langkah tambahan untuk menyelesaikan masalah apriori dan untuk menghasilkan aturan asosiasi yang relevan (Janwe, 2011). Algoritma GARW digunakan dalam proses web crawler dalam menemukan pengetahuan yang berguna dari hasil pencarian. Web crawler adalah sistem untuk mengunduh sebagian besar halaman web, pada pengelolaan informasinya web crawler tidak terpusat pada repository atau datasource tertentu, melainkan terdiri dari ratusan juta 
penyedia konten web yang independen, masing-masing menyediakan layanan mereka sendiri (Christopher Olston, 2010). Berdasarkan pemaparan tersebut peneliti akan membuat analisis text mining menggunakan algoritma association rule extraction GARW untuk menemukan pengetahuan dari hasil pencarian web crawler pada search engine, hasil dari pencarian search engine, memiliki banyak sekali tautan konten web akan di ekstrak untuk diambil informasi yang relevan berdasarkan kata kunci yang diinputkan.

\section{METODOLOGI}

Web crawler (juga dikenal sebagai robot web atau spider) adalah sebuah program untuk men-download Halaman web. Melakukan download halaman yang sesuai, ekstrak semua URL yang terkandung di dalamnya, dan menambahkan setiap URL yang sebelumnya tidak diketahui. Web crawler mencoba untuk mencari dan mengambil halaman web yang relevan dengan domain yang spesifik (Najork \& Heydon, 2001).

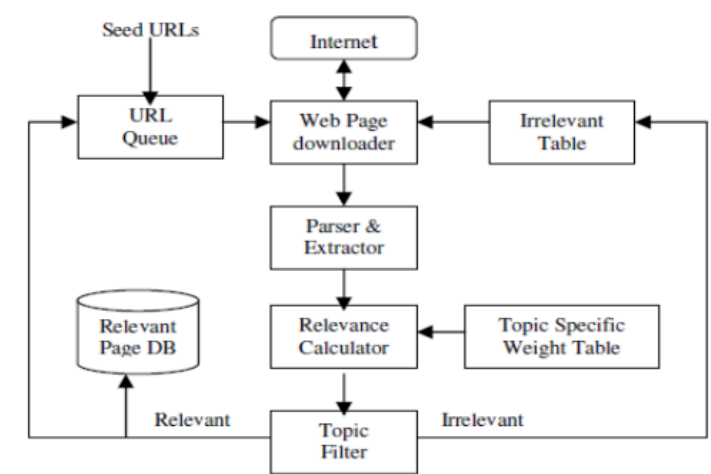

Gambar 2. Arsitektur web crawler

Pada gambar diatas web crawler fokus mengambil konten dari halaman yang relevan yang secara bersamaan melintasi sejumlah minimal dokumen / list pencarian yang tidak atau kurang relevan di web. Dalam web crawler, seed URL digunakan untuk meninisialisasi proses crawling. Setiap URL yang dikunjungi oleh web crawler ini mengidentifikasi hyperlink yang berbeda di halaman yang berbeda dari internet oleh parser dan generator yang disimpan dalam sistem basis data mesin pencari (Kulkarni, 2016).

Berikut adalah gambar Generate Association Rule with Weight (GARW) untuk membangkitkan penemuan pengetahuan secara umum dilakukan melalui tiga tahapan (Kulkarni, 2016) :

1. Text Pre-processing

2. Association rule mining

3. Visualization stage 


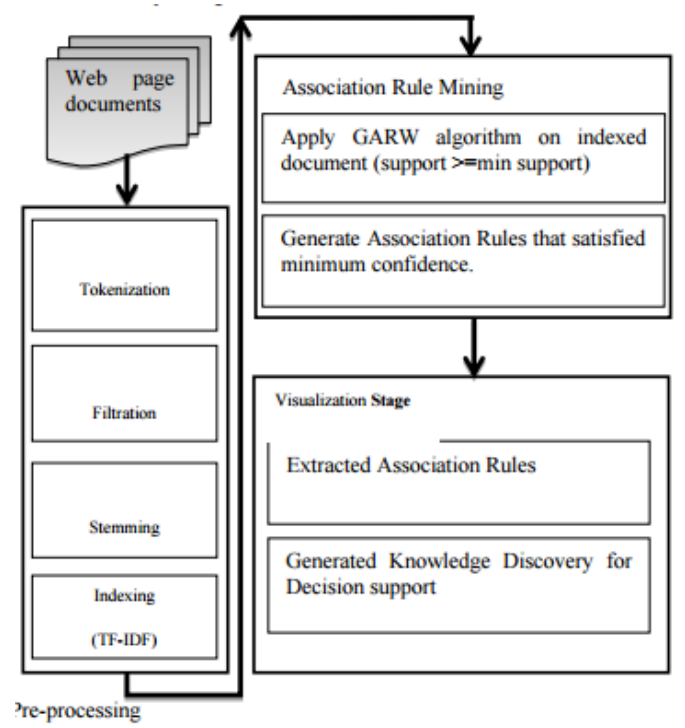

Gambar 3. Blok diagram untuk penemuan pengetahuan menggunakan association rule

Keterangan :

\section{Tokenization}

Tokenisasi adalah proses memisahkan teks ke dalam kata-kata atau istilah. Fase ini memainkan peran yang sangat penting dalam menghasilkan aturan asosiasi. Tujuan utamanya adalah untuk mengkonversi dokumen tidak terstruktur ke dalam dokumen terstruktur. Halaman web biasanya berisi informasi dalam format yang tidak terstruktur. ini membuat masalah bagi pertambangan teks yang akurat dan relevan. Oleh karena itu diperlukan untuk mengkonversi informasi tidak terstruktur untuk format yang terstruktur.

2. Filtration

Mencari informasi yang diharapkan memiliki output yang relevan dari pencarian. Dalam pencarian informasi terdapat pesoalan bahwa input script mengandung terlalu banyak kata-kata atau tag yang beragam dengan struktur yang berbeda. Untuk menghasilkan pengetahuan yang akurat dari koleksi halaman web, pengguna perlu untuk mengetahui hubungan antara semua kata kunci namun peran ini dapat menjadi tidak efisien jika kita tidak menghapus kata-kata atau scipt yang yang tidak dibutuhkan pada dokumen input. pada tahapan ini hasil pencarian pada halaman web yang dapat berupa kalimat, paragraf atau dokumen dibagi menjadi bagian-bagian tertentu'kemudian token disaring dengan menghapus stop words dan sufiks untuk mencapai hasil penemuan pengetahuan yang lebih baik. Adapun stop words yang harus di hapus adalah seperti pada tabel 1.

Tabel 1. Stop words Bahasa Indonesia dan Inggris

\begin{tabular}{|c|c|}
\hline Stop words Bahasa Inggris & $\begin{array}{c}\text { Stop words Bahasa Indonesia } \\
\text { (Tala, 2003). }\end{array}$ \\
\hline $\begin{array}{l}\text { a, able, about, across, after, all, } \\
\text { almost, also, am, among, an, and, } \\
\text { any, are, as, at, be, because, been, } \\
\text { but, by, can, cannot, could, dear, } \\
\text { did, do, does, either, else, ever, } \\
\text { every, for, from, get, got, had, has, } \\
\text { have, he, her, hers, him, his, how, } \\
\text { however, i, if, in, into, is, it, its, just, } \\
\text { least, let, like, likely, may, me, } \\
\text { might, most, must, my, neither, no, }\end{array}$ & $\begin{array}{l}\text { ada, adalah, adanya, adapun, agak, } \\
\text { agaknya, agar, akan, akankah, akhir, } \\
\text { akhiri, akhirnya, aku, akulah, amat, } \\
\text { amatlah, anda, andalah, antar, antara, } \\
\text { antaranya, apa, apaan, apabila, apakah, } \\
\text { apalagi, apatah, artinya, asal, asalkan, } \\
\text { atas, atau, ataukah, ataupun, awal, } \\
\text { awalnya, bagai, bagaikan, bagaimana, } \\
\text { bagaimanakah, bagaimanapun, bagi, } \\
\text { bagian, bahkan, bahwa, bahwasanya, }\end{array}$ \\
\hline
\end{tabular}


nor, not, of, off, often, on, only, or, other, our, own, rather, said, say, says, she, should, since, so, some, than, that, the, their, them, then, there, these, they, this, tis, to, too, twas, us, wants, was, we, were, what, when, where, which, while, who, whom, why, will, with, would, yet, you, your

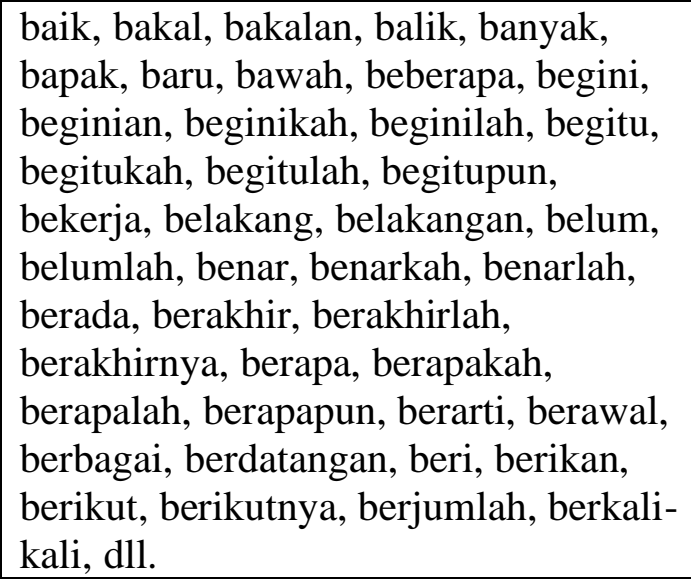

\section{3. $\quad$ Stemming}

Adalah sebuah proses di mana bentuk-bentuk varian dari kata yang sama dikurangi sehingga menjadi bentuk yg umum. Hal ini penting untuk memahami bahwa kita menggunakan stemming ini dengan tujuan untuk meningkatkan kinerja sistem penemuan pengetahuan. Algoritma porter adalah proses untuk menghapus suffix dari kata-kata dalam bahasa inggris. Pada table 2 berikut menunjukan beberapa peraturan yang dimodifikasi menggunakaan algoritma porter.

Table 2. Modifikasi pada Aturan Porter Stemming Bahasa Inggris

\begin{tabular}{|l|l|l|l|l|}
\hline No & $\begin{array}{l}\text { Rule } \\
\text { added/Changed }\end{array}$ & Example & $\begin{array}{l}\text { Output by } \\
\text { original Porter }\end{array}$ & $\begin{array}{l}\text { Output by } \\
\text { modified Porter }\end{array}$ \\
\hline 1 & OUS -> OUS & Obvious & Obviou & Obvious \\
\hline 2 & ICAL -> ICAL & Medical & Medice & Medical \\
\hline 3 & IAL ->E & Official & Offici & Office \\
\hline 4 & ANT->ANT & Servant & Serv & Servant \\
\hline 5 & DENT-DENT & Accident & Accid & Accident \\
\hline 6 & ATION-> ATE & Corporat ion & Corpor & Corporate \\
\hline 7 & E -> E & Village & Villag & Village \\
\hline After removal of "ing" character use replacement rule: \\
\hline 8 & S -> SE & Exposing & Expos & \\
\hline After removal of ,ed ${ }^{\text {ee }}$ character use replacement rule: \\
\hline 9 & R -> RE & Declared & Declar \\
\hline 10 & D -> DE & Provided & Provid & Declare \\
\hline 11 & G $>$ GE & Emerged & Emerg & Provide \\
\hline 12 & V $>$ VE & Removed & Remov & Emerge \\
\hline 13 & FI $>$ FY & Identified & Identifi & Identify \\
\hline
\end{tabular}

Adapun tahapan dalam proses stemming dalam bahasa indonesia adalah sebagai berikut :

a. Hapus Particle

b. Hapus Possesive Pronoun

c. Hapus awalan pertama. Jika tidak ada lanjutkan ke langkah 4a,jika ada cari maka lanjutkan ke langkah $4 \mathrm{~b}$

d. i). Hapus awalan kedua, lanjutkan ke langkah 5a

ii). Hapus akhiran, jika tidak ditemukan maka kata tersebut diasumsikan sebagai root word. Jika ditemukan maka lanjutkan ke langkah 5b.

e. i). Hapus akhiran. Kemudian kata akhir diasumsikan sebagai root word 
4. Indexing

ii). Hapus awalan kedua. Kemudian kata akhir diasumsikan sebagai root word.

Skema pembobotan TF-IDF (Term Frequency, Inverse Document Frequency) digunakan untuk menetapkan bobot untuk membedakan istilah dalam dokumen. Frekuensi istilah hitungan yang mewakili berapa kali kata kunci (x) telah terjadi dalam dokumen. Frekuensi dokumen invers adalah hitungan yang mewakili jumlah total dokumen yang berisi kata kunci (x) setidaknya sekali. Kami telah menggunakan metode TF-IDF untuk mendapatkan penemuan pengetahuan yang relevan hanya untuk menghitung total kata kunci dalam dokumen masukan. Adapun rumus untuk menentukan TF adalah (Kulkarni, 2016):

Diketahui :

$$
(t f)_{i, j}=\sum_{i=j=1}^{n}\left(N t_{1}, d_{n j}\right)
$$

$\mathrm{Nt}_{\mathrm{i}}, \mathrm{d}=$ Jumlah istilah $\mathrm{t}_{\mathrm{i}}$ yang terjadi di dalam dokumen $\mathrm{d}_{\mathrm{j}}$

Inverse Document Frequency (Kulkarni, 2016)

$$
(\text { idf })_{i, j}=\sum_{i=j=1}^{n} \log \left(\frac{|C|}{N t_{i}}\right)
$$

Diketahui :

$\mathrm{Nt}_{\mathrm{i}}$ menunjukan jumlah dokumen dalam koleksi $\mathrm{C}$, dimana $\mathrm{t}_{\mathrm{i}}$ terjadi setidaknya sekali.dan $|\mathrm{C}|$ menunjukan total dari dokumen.

\section{Vector Space Model - Cosine Similarity}

Formally, a vector space is defined by a set of linearly independent basis vectors Setelah memiliki bobot dengan istilah yang berbeda menggunakan TF / IDF, pengecekan kesamaan antara query dan isi pada dokumen web diperlukan untuk menghitung ambang batas threshold berdasarkan kesamaan istilah (Bathla \& Jindal, 2011). Model Ruang Vektor digunakan untuk menghitung kesamaan ini (Bathla \& Jindal, 2011):

$$
\begin{aligned}
& |D i|=\sqrt{w} d^{2} \\
& |Q|=\sqrt{w} q^{2} \\
& \operatorname{Cosin} \mathrm{e} \emptyset d i=\frac{Q . D i}{|Q| \cdot|D i|} \\
& \operatorname{Sim}(\mathrm{Q}, \mathrm{Di})=\operatorname{Cosin} \mathrm{e} \emptyset d i
\end{aligned}
$$

Dimana Q.Di adalah dot produk dari bobot query .

$|\mathrm{Q}|$ merupakan panjang dari query vector

|Di| merupakan panjang dari dokumen vector

Association Rule terdiri dari struktur IF-ELSE yang dapat memprediksi atribut kombinasi. Untuk setiap konsekuen aturan IF THEN kita menghitung support dan confidence yang cocok dengan nilai-nilai yang ditentukan (Bathla \& Jindal, 2011). Dalam association rule ini dihasilkan dari association rule yang memenuhi kriteria seperti support, confidence, dan nilai TF-IDF kata kunci. Algoritma ini disebut sebagai GARW (Generating Association Rule using Weighting Scheme). Algoritma GARW beroperasi dengan cara yang sama seperti algoritma Apriori akan tetapi ditambahkan dengan beberapa langkah tambahan untuk menyelesaikan masalah Apriori dan untuk menghasilkan aturan asosiasi yang relevan (Bhujade \& Janwe, 2011). Adapun Algoritma GARW secara deskriptif dijelaskan sebagai berikut (Kulkarni, 2016):

1. Pindai file yang berisi semua kata kunci yang memenuhi nilai ambang batas (threshold weight) dan frekuensi masing-masing dokumen. 
2. "N" menunjukkan jumlah kata kunci atas yang memenuhi nilai bobot threshold,

3. Letakkan paling atas kata kunci $\mathrm{N}$ dalam daftar indeks bersama dengan nilai TFdi dalam semua daftar,

4. Gunakan minimum support dan confidence untuk mengenerate association rule,

5. Scan list index dan temukan semua kata kunci yang memenuhi ambang batas dukungan minimal,

6. Dalam $\mathrm{K}>=2$, kandidat kata kunci $\mathrm{C}_{k}$, dimana nilai $\mathrm{k}$ di hasilkan dari set kata kunci.

7. Pindai daftar indeks dan frekuensi menghitung dari set kata kunci $\mathrm{C}_{\mathrm{k}}$ yang dihasilkan pada langkah 5,

8. Bandingkan frekuensi set calon kata kunci dengan minimum support,

9. Set kata kunci k yang memenuhi minimum support, temukan dari langkah 6,

10. Untuk setiap set kata kunci yang sering muncul, temukan semua asosiasi aturan yang memenuhi ambang minimum confidence.

\section{HASIL DAN PEMBAHASAN}

\subsection{Business Understanding}

Pada tahapan ini difokuskan pada memahami kebutuhan dan tujuan peneliti dari sudut pandang bisnis, pada pencarian di internet pengguna perlu mencari tahu hubungan antara semua kata kunci yang ada di halaman web halaman tersebut, bagi pengguna membaca kumpulan dokumen dan mendapatkan beberapa pengetahuan memakan waktu dan kurang efektif. Pada penelitian ini peneliti akan mempermudah proses pencarian dengan mengambil konten konten tertentu yang perlu berdasarkan pemilihan kata kunci dan kategori .

\subsection{Data Understanding}

Sumber data berasal dari konten halaman web dari hasil pencarian search engine google, data dari konten halaman web tersebut yang berupa dokumen tag html akan dilakukan ekstraksi untuk mendapatkan konten artikel utama pada laman tersebut. Konten yang dihasilkan dari hasil pencarian berdasarkan kata kunci ini awalnya masih berupa konten HTML yang memiliki struktur yang bervariasi yang merupakan data semi terstruktur, multi bahasa, serta banyak tag HTML yang tidak diperlukan yang perlu untuk di bersihkan.

\subsection{Data Preparation}

Data dari internet perlu dilakukan pembersihan data dari konten yang tidak perlu secara otomatis. Mekanisme pembersihan data adalah sebagai berikut :

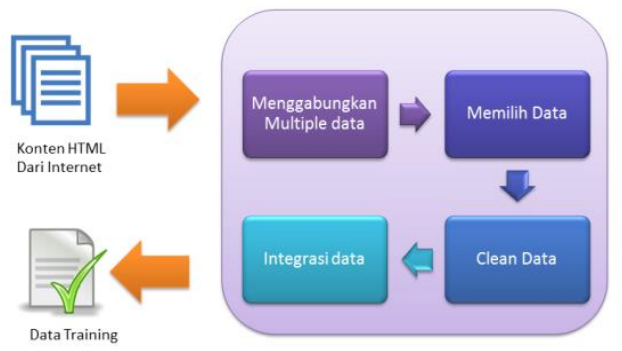

\section{Gambar 4. Tahapan dalam Data Preparation}

Keterangan :

1. Menggabungkan Multiple Data

Konten dari internet dapat berasal dari laman yang memiliki struktur HTML berbeda, dan dari sumber data yang berbeda-beda dari jutaan server di dunia. Untuk bahan analisa peneliti mengambil sample dari hasil pencarian yang didapat beberapa link URL dan konten berikut, dalam kasus ini kata kunci yang digunakan sebagai bahan untuk analisis adalah "text mining", dengan total pencarian konten di internet penulis membatasi 100 
laman konten web, namun dalam pembahasan analisis dalam menemukan pengetahauan konten yang di jelaskan adalah 5 laman konten web, mewakili semua laman hasil pencarian.

Tabel 3. Data Laman Konten Web

\begin{tabular}{|c|c|}
\hline Alamat URL & Konten \\
\hline $\begin{array}{l}\text { http://searchsqlserv } \\
\text { er.techtarget.com/d } \\
\text { efinition/data- } \\
\text { mining }\end{array}$ & $\begin{array}{l}\text { <html class="gt-ie8 js no-touch csstransforms } \\
\text { csstransforms3d csstransitions mti-inactive" dir="ltr" } \\
\text { lang="en" prefix="og: http://ogp.me/ns\#" itemscope="" } \\
\text { itemtype="http://schema.org/Article" style="" ><!-- } \\
<![\text { endif]--><head }><\text { script } \\
\text { src="http://pagead2.googlesyndication.com/pagead/osd.js"> } \\
</ \text { script }><\text { script } \\
\text { src="https://securepubads.g.doubleclick.net/gampad/ads?gdf } \\
\text { p_req=1\&amp;correlator=779309671201869\&amp;output=j } \\
\text { son_html\&amp;callback=googletag.impl.pubads.callbackPro } \\
\text { xy5\&amp;impl=fif\&amp;eid=108809107\%2C21060362\%2 } \\
\text { C21060364\&amp;sc=0\&amp;sfv }=1-0-. . . \\
\text { to predict future trends. }<b></ b></ p>\ldots\end{array}$ \\
\hline $\begin{array}{l}\text { https://en.wikipedia } \\
\text {.org/wiki/Data_min } \\
\text { ing }\end{array}$ & 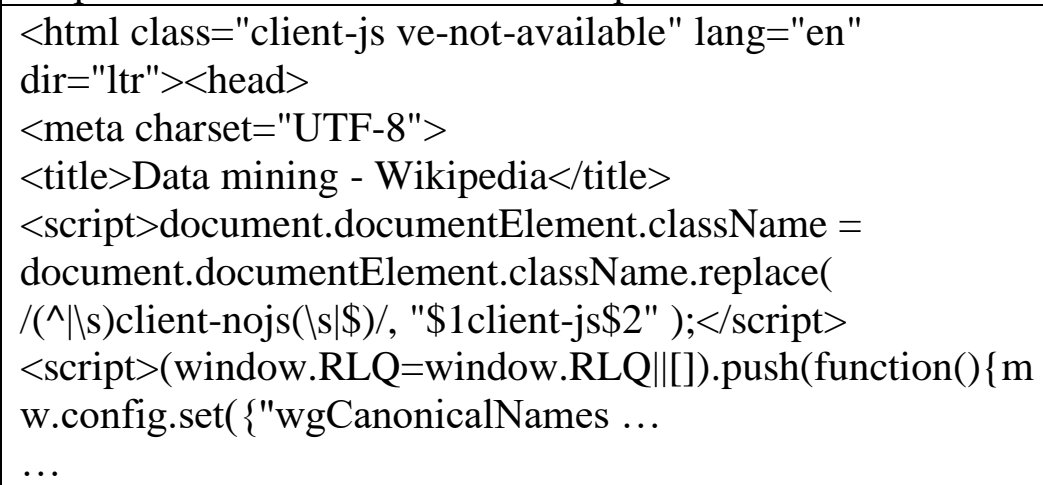 \\
\hline $\begin{array}{l}\text { https://docs.oracle. } \\
\text { com/cd/B28359_01 } \\
\text { /datamine.111/b28 } \\
\text { 129/process.htm }\end{array}$ & 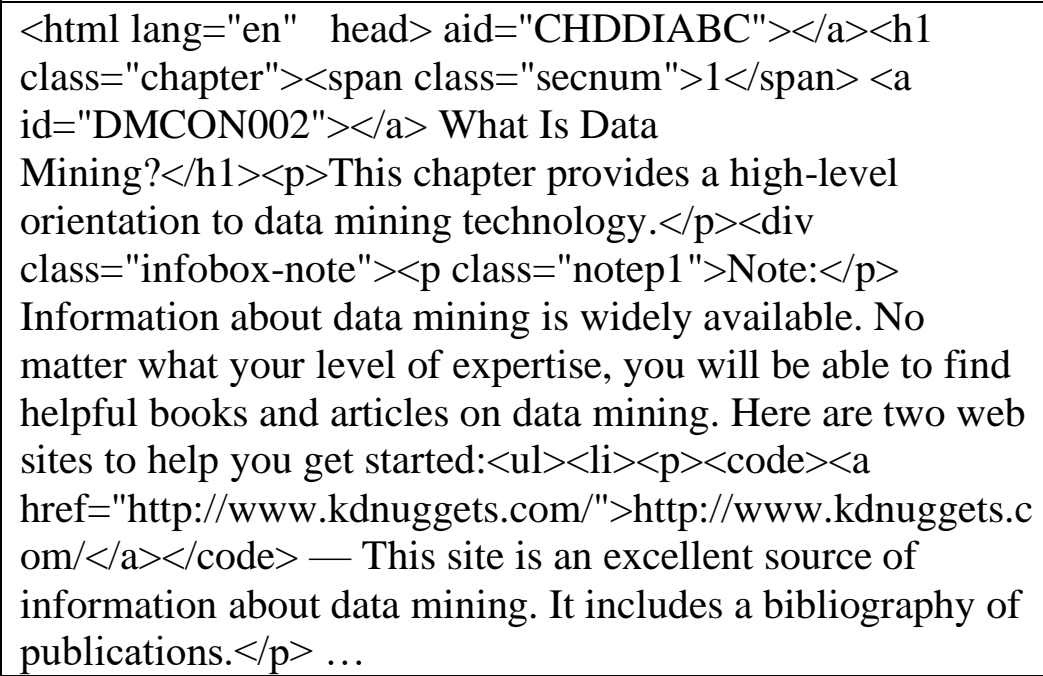 \\
\hline $\begin{array}{l}\text { https://id.wikipedia } \\
\text {.org/wiki/Penggalia } \\
\text { n_data }\end{array}$ & $\begin{array}{l}<\text { html class="client-js ve-available" lang="id" } \\
\text { dir="ltr" }><\text { head }> \\
<\text { meta charset="UTF-8"> } \\
<\text { title }>\text { Penggalian data }- \text { Wikipedia bahasa Indonesia, } \\
\text { ensiklopedia bebas }</ \text { title }> \\
<\text { script }>\text { document.documentElement.className = } \\
\text { document.documentElement.className.replace }( \\
/(\wedge|| s) \text { client-nojs }(\backslash \mathrm{s} \mid \$) /, \text { " } \$ \text { client-js } \$ 2 ") ;</ \text { script }>\end{array}$ \\
\hline
\end{tabular}




\begin{tabular}{|c|c|}
\hline & $\begin{array}{l}<\text { script }>\text { (window.RLQ=window.RLQ\|[]).push(function }()\{\mathrm{m} \\
\text { w.config.set( }\{\text { "wgCanonicalNamespace":"","wgCanonicalSp } \\
\text { ecialPageName":false,"wgNamespaceNumber":0,"wgPageN } \\
\text { ame":"Penggalian_data", } \ldots .<\text { a href="\#cite_note- } \\
1 \text { 1">[1]</a }></ \text { sup }>\text {. Suatu pola dikatakan menarik apabila } \\
\text { pola tersebut tidak sepele, implisit, tidak diketahui } \\
\text { sebelumnya, dan berguna. Pola yang disajikan haruslah } \\
\text { mudah dipahami, berlaku untuk data yang akan diprediksi } \\
\text { dengan derajat kepastian tertentu, berguna, dan baru. } \\
\text { Penggalian data memiliki beberapa nama alternatif, } \\
\text { meskipun definisi eksaknya berbeda, seperti KDD } \\
\text { (knowledge discovery in database), analisis pola, arkeolog... }\end{array}$ \\
\hline $\begin{array}{l}\text { http://www.thearlin } \\
\text { g.com/text/dmwhit } \\
\text { e/dmwhite.htm }\end{array}$ & $\begin{array}{l}<\text { html }><\text { head }> \\
<\text { meta http-equiv="Content-Type" content="text/html; } \\
\text { charset=iso-8859-1"><meta name="description" } \\
\text { content="An Introduction to Data Mining" }><\text { meta } \\
\text { name="keywords" content="consult, consulting, consultant, } \\
\text { data mining, database marketing, database mining, data } \\
\text { analysis, dss, decision support, olap, kdd, kdnuggets, } \\
\text { knowledge discovery, data visualization, information design, } \\
\text { information visualization, one to one marketing, one-to-one } \\
\text { marketing, marketing, kurt thearling, thearling"> } \\
<\text { meta name="GENERATOR" content="Microsoft } \\
\text { FrontPage } 4.0 "> \\
<\text { title>An Introduction to Data Mining }</ \text { title }>. .<p>\text { Data } \\
\text { mining, <em>the extraction of hidden predictive information } \\
\text { from large } \\
\text { databases }</ \text { em }>\text {, is a powerful new technology with great } \\
\text { potential to help } \\
\text { companies focus on the most important information in their } \\
\text { data warehouses. Data mining } \\
\text { tools predict future trends and behaviors, allowing } \\
\text { businesses to make proactive, } \\
\text { knowledge-driven decisions. The automate ... }\end{array}$ \\
\hline
\end{tabular}

2. Memilih Data

Konten yang diambil dari halaman web tersebut merupakan konten yang terdapat pada tag title, pageTitle, content, bodyContent, pageContent, content-center, article dari masingmasing laman yang didapatkan dari hasil pencarian. Id Tag div yang di tentukan penulis berdasarkan hasil ektraksi dari beberapa url, didapat beberapa penamaan tag div dengan id konten yang beragam, namun peneliti mencoba mengidentifikasi penamaan id konten yang umumnya digunakan dalam laman web.

3. Membersihkan Data

Tag tag pada konten HTML yang tidak dibutuhkan akan dihilangkan.hanya konten yang terdapat dalam konten utama yang akan di pertahankan.dari table 5.1, tag html yang tidak diperlukan akan dihilangkan, kemudian tag yang berada dalam id content akan diambil sebagai data training, berikut hasil pembersihan data yang ditampilkan dalam table 4.2.

\section{Tabel 4. Konten data training yang telah dibersihkan} Konten 


\begin{tabular}{|c|c|}
\hline $\begin{array}{l}\text { http://searchsqlserver. } \\
\text { techtarget.com/definit } \\
\text { ion/data-mining }\end{array}$ & $\begin{array}{l}\text { Data mining is the process of sorting through large data } \\
\text { sets to identify patterns and establish relationships to solve } \\
\text { problems through data analysis. Data mining tools allow } \\
\text { enterprises to predict future trends. Download this free } \\
\text { guide Download Our Exclusive Big Data Analytics Guide } \\
\text { An unbiased look at real-life analytics success stories, } \\
\text { including a Time Warner Cable case study, and tips on } \\
\text { how to evaluate big data tools. This guide will benefit BI } \\
\text { and analytics pros, data scientists, business execs and } \\
\text { project managers. Start Download Corporate E-mail } \\
\text { Address: You forgot to provide an Email Address. This } \\
\text { email address doesn't appear to be valid. This email } \\
\text { address is already registered. Please login. You have } \\
\text { exceeded the maximum character limit. Please provide a } \\
\text { Corporate E-mail Address. .... }\end{array}$ \\
\hline $\begin{array}{l}\text { https://en.wikipedia.o } \\
\text { rg/wiki/Data_mining }\end{array}$ & $\begin{array}{l}\text { Data mining is the computing process of discovering } \\
\text { patterns in large data sets involving methods at the } \\
\text { intersection of machine learning, statistics, and database } \\
\text { systems.[1] It is an interdisciplinary subfield of computer } \\
\text { science.[1][2][3] The overall goal of the data mining } \\
\text { process is to extract information from a data set and } \\
\text { transform it into an understandable structure for further } \\
\text { use.[1] Aside from the raw analysis step, it involves } \\
\text { database and data management aspects, data pre- } \\
\text { processing, model and inference considerations, } \\
\text { interestingness metrics, complexity considerations, post- } \\
\text { processing of discovered structures, visualization, and } \\
\text { online updating. Data mining is the analysis step of the } \\
\text { "knowledge discovery in databases" process, or KDD. The } \\
\text { term is a misnomer, because the goal is the extraction of } \\
\text { patterns and knowledge from large amounts of data ... }\end{array}$ \\
\hline $\begin{array}{l}\text { https://docs.oracle.co } \\
\mathrm{m} / \mathrm{cd} / \mathrm{B} 28359 \_01 / \mathrm{dat} \\
\text { amine.111/b28129/pr } \\
\text { ocess.htm }\end{array}$ & $\begin{array}{l}\text { Data mining is the practice of automatically searching } \\
\text { large stores of data to discover patterns and trends that go } \\
\text { beyond simple analysis. Data mining uses sophisticated } \\
\text { mathematical algorithms to segment the data and evaluate } \\
\text { the probability of future events. Data mining is also } \\
\text { known as Knowledge Discovery in Data (KDD). The key } \\
\text { properties of data mining are: Automatic discovery of } \\
\text { patterns Prediction of likely outcomes Creation of } \\
\text { actionable information Focus on large data sets and } \\
\text { databases Data mining can answer questions that cannot } \\
\text { be addressed through simple query and reporting } \\
\text { techniques. Automatic Discovery Data mining is } \\
\text { accomplished by building models. A model uses an } \\
\text { algorithm to act on a set of data. The notion of automatic } \\
\text { discovery refers to the execution of data mining models. }\end{array}$ \\
\hline $\begin{array}{l}\text { https://id.wikipedia.or } \\
\text { g/wiki/Penggalian_da } \\
\text { ta }\end{array}$ & $\begin{array}{l}\text { Penggalian data (bahasa Inggris: data mining) adalah } \\
\text { ekstraksi pola yang menarik dari data dalam jumlah } \\
\text { besar }{ }^{[1]} \text {. Suatu pola dikatakan menarik apabila pola } \\
\text { tersebut tidak sepele, implisit, tidak diketahui sebelumnya, }\end{array}$ \\
\hline
\end{tabular}




\begin{tabular}{|c|c|}
\hline & $\begin{array}{l}\text { dan berguna. Pola yang disajikan haruslah mudah } \\
\text { dipahami, berlaku untuk data yang akan diprediksi dengan } \\
\text { derajat kepastian tertentu, berguna, dan baru. Penggalian } \\
\text { data memiliki beberapa nama alternatif, meskipun definisi } \\
\text { eksaknya berbeda, seperti KDD (knowledge discovery in } \\
\text { database), analisis pola, arkeologi data, pemanenan } \\
\text { informasi, dan intelegensia bisnis. Penggalian data } \\
\text { diperlukan saat data yang tersedia terlalu banyak } \\
\text { (misalnya data yang diperoleh dari sistem basis } \\
\text { dataperusahaan, e-commerce, data saham, dan } \\
\text { data bioinformatika), tetapi tidak tahu pola apa yang bisa } \\
\text { didapatkan. ... }\end{array}$ \\
\hline $\begin{array}{l}\text { http://www.thearling. } \\
\text { com/text/dmwhite/dm } \\
\text { white.htm }\end{array}$ & $\begin{array}{l}\text { An Introduction to Data Mining } \\
\text { Discovering hidden value in your data warehouse } \\
\text { Data mining, the extraction of hidden predictive } \\
\text { information from large databases, is a powerful new } \\
\text { technology with great potential to help companies focus } \\
\text { on the most important information in their data } \\
\text { warehouses. Data mining tools predict future trends and } \\
\text { behaviors, allowing businesses to make proactive, } \\
\text { knowledge-driven decisions. The automated, prospective } \\
\text { analyses offered by data mining move beyond the analyses } \\
\text { of past events provided by retrospective tools typical of } \\
\text { decision support systems. Data mining tools can answer } \\
\text { business questions that traditionally were too time } \\
\text { consuming to resolve. They scour databases for hidden } \\
\text { patterns, finding predictive information that experts may } \\
\text { miss because it lies outside their expectations. }\end{array}$ \\
\hline
\end{tabular}

4. Integrasi Data

Konten data training, kemudian disimpan ke dalam basis data penyimpanan sementara (Array Map) atau database sebagai data training. Array Map seperti pada dekalrasi map dibawah ini.

Map $<$ String, String $>$ map = new HashMap $<$ String, String $>()$;

Merupakan variable yang bertipe string.yang berisi data training yang telah di bersihkan.

Data yang tersimpan baik dalam Array Map atau database telah distrukturkan sehingga memudahkan dalam proses preprocessing selanjutnya.

5. Tokenization

Pada tahapan tokenisasi ini memisahkan teks dalam kalimat menjadi beberapa bagian, dalam data yang didapat dari hasil pencarian, setiap kata di bagi seperti pada gambaran berikut :

Tabel 5. Tokenization

\begin{tabular}{|l|l|l|}
\hline No & \multicolumn{1}{|c|}{ Alamat URL } & \multicolumn{1}{c|}{ Konten } \\
\hline 1 & http://searchsqlserver.techt & Data|mining|is|the|process|of|sorting|through|lar \\
& arget.com/definition/data- & ge|data|sets|to|identify|patterns|and|establish|rel \\
& mining & ationships|to|solve|problems|through|data|analy \\
& & sis.|Data|mining|tools|allow|enterprises|to|predi \\
& & ct|future|trends.|Download|this|free|guide|Down \\
& & load|Our|Exclusive|Big|Data|Analytics|Guide|A \\
& & n|unbiasedlook|at|real- \\
& & life|analytics|success|stories,| \\
\hline
\end{tabular}




\begin{tabular}{|c|c|c|}
\hline & & $\begin{array}{l}\text { including|a|time|Warner|Cable|case|study|and|ti } \\
\text { ps|on|how|to|evaluate|big|data|tools.| }\end{array}$ \\
\hline 2 & $\begin{array}{l}\text { https://en.wikipedia.org/wi } \\
\text { ki/Data mining }\end{array}$ & $\begin{array}{l}\text { Data|mining|is|the|computing|process|of|discov } \\
\text { ering|patterns|in|large|data|sets|involving|metho } \\
\text { ds|at|the|intersection|of|machine|learning,|statist } \\
\text { ics,|and|database|systems.[1]|It|is|an|interdiscipl } \\
\text { inary|subfield|of|computer|science|The|overall|g } \\
\text { oal|of } \\
\text { |the|data|mining|process|is|to|extract|informatio } \\
\text { n|from|a|data| } \\
\text { set|and|transform|it|into|an|understandable|struc } \\
\text { ture|for } \\
\text { |further|use }\end{array}$ \\
\hline 3 & $\begin{array}{l}\text { https://docs.oracle.com/cd/ } \\
\text { B28359_01/datamine.111/ } \\
\text { b28129/process.htm }\end{array}$ & $\begin{array}{l}\text { What|Is|Data|Mining?|What|Can|Data|Mining| } \\
\text { Do|and|Not|Do?| } \\
\text { The|Data|Mining|Process|What|Is } \\
\text { |Data|Mining?| } \\
\text { Data|mining|is|the|practice|of|automatically|sear } \\
\text { ching|large|stores|of|data|to|discover|patterns|an } \\
\text { d|trends|that|go|beyond|simple|analysis|Data|mi } \\
\text { ning|uses|sophisticated|mathematical|algorithm } \\
\text { s|to|segment|the|data|and|evaluate|the|probabilit } \\
\text { y|of|future|events|Data|mining|is|also|known|as| } \\
\text { Knowledge|Discovery|in|Data|(KDD). }\end{array}$ \\
\hline 4 & $\begin{array}{l}\text { https://id.wikipedia.org/wi } \\
\text { ki/Penggalian_data }\end{array}$ & $\begin{array}{l}\text { Penggalian|data|(Bahasa|Inggris|data|mining)|a } \\
\text { dalah } \\
\text { |ekstraksi|pola|yang|menarik|dari|data|dalam|ju } \\
\text { mlah|besar|. } \\
\text { Suatu|pola|dikatakan|menarik|apabila|pola|terse } \\
\text { but|tidak|sepele,|implisit,|tidak|diketahui|sebelu } \\
\text { mnya,|dan|berguna.|Pola|yang|disajikan|harusla } \\
\text { h|mudah|dipahami,|berlaku|untuk|data|yang|aka } \\
\text { n|diprediksi|dengan|derajat|kepastian|tertentu,|b } \\
\text { erguna,|dan|baru|Penggalian|data|memiliki|bebe } \\
\text { rapa|nama|alternative|meskipun|definisi|eksakn } \\
\text { ya|berbeda,|seperti|KDD|(knowledge|discovery| } \\
\text { in|database),|analisis|pola,|arkeologi|data,| } \\
\text { pemanenan|informasi,|dan|intelegensia|bisnis. }\end{array}$ \\
\hline 5 & $\begin{array}{l}\text { http://www.thearling.com/t } \\
\text { ext/dmwhite/dmwhite.htm }\end{array}$ & $\begin{array}{l}\text { An|Introduction|to|Data|Mining|Discovering|hi } \\
\text { dden|value|in|your|data|warehouse|Data|mining, } \\
\text { |the|extraction|of|hidden } \\
\text { |predictive|information|from|large|databases,|is| } \\
\text { a|powerful } \\
\text { new|technology|with|great|potential|to|help|com } \\
\text { panies|focus |on } \\
\text { |the|most|important|information|in|their|data|wa } \\
\text { rehouses.|Data|mining|tools|predict|future|trend } \\
\text { s|and|behaviors,|allowing } \\
\text { |businesses|to|make|proactive,|knowledge- } \\
\text { driven|decisions.|The|automated,|prospective|an }\end{array}$ \\
\hline
\end{tabular}




\begin{tabular}{|l|l|}
\hline & alyses \\
& |offered|by|data|mining|move|beyond|the|analys \\
& es|of|past \\
& |events|provided|by|retrospective|tools|typical|o \\
& f|decision|support|systems.|Data|mining|tools|ca \\
& n|answer|business \\
& |questions|that|traditionally|were|too|time|consu \\
& ming|to |resolve.
\end{tabular}

6. Filtration of Keyword

Setelah teks tersebut dibagi menjadi kata per kata, selanjutnya kata yang mengandung unsur stop word dihapus.

Tabel 6. Filtration of Keyword

\begin{tabular}{|c|c|c|}
\hline No & Alamat URL & Konten \\
\hline 1 & $\begin{array}{l}\text { http://searchsqlserver.tech } \\
\text { target.com/definition/data } \\
\text {-mining }\end{array}$ & $\begin{array}{l}\text { Data|mining| } \\
\text { |process|sort|through|large|data|set|identify|pattern|e } \\
\text { stablish|relation|solve|problem|through|data|analysi } \\
\text { s.|Data| mining } \\
\text { |tool|allow|enterprise|predict|future|trend.|Downloa } \\
\text { d| } \\
\text { free|guide|Download|Our|Exclusive|Big|Data|Analy } \\
\text { tic|Guide|unbiasedlook| real- } \\
\text { life|analytic|success|story| include| } \\
\text { time|Warner|Cable|case|studytips|evaluate|big|data|t } \\
\text { ool... }\end{array}$ \\
\hline 2 & $\begin{array}{l}\text { https://en.wikipedia.org/w } \\
\text { iki/Data_mining }\end{array}$ & $\begin{array}{l}\text { Data| } \\
\text { mining|compute|process|discover|pattern|large|data| } \\
\text { set|involve|method|intersect|machine|learn|statistic| } \\
\text { database|system|interdisciple|field|computer|science } \\
\text { |overall|goal| } \\
\text { data|mining|process|extract|information|data| } \\
\text { |transform|understandable|structure|for } \\
\text { |further|use... }\end{array}$ \\
\hline 3 & $\begin{array}{l}\text { https://docs.oracle.com/cd } \\
\text { /B28359_01/datamine.11 } \\
\text { 1/b28129/process.htm }\end{array}$ & $\begin{array}{l}\text { Data| mining |Data| mining |Data| mining } \\
\text { |Process|Data| mining | Data|mining| |practice| } \\
\text { automatically|searching|large|stores| data| } \\
\text { discover|pattern|trend|go|beyond|simple|analysis|Da } \\
\text { ta | mining |use|sophisticate|mathematic|algorithm| } \\
\text { segment|data|evaluate|probability|future|event|Data } \\
\text { | mining } \\
\text { |known|Knowledge|Discovery|Data|(KDD)... }\end{array}$ \\
\hline 4 & $\begin{array}{l}\text { https://id.wikipedia.org/w } \\
\text { iki/Penggalian_data }\end{array}$ & $\begin{array}{l}\text { penggalian|data|Bahasa|Inggris|data|mining|ekstrak } \\
\text { si|pola| } \mid \text { data| jumlah| pola|pola| implisit| } \\
\text { Pola|disajikan|haruslah| } \\
\text { mudah|paham|laku|data|prediksi|derajat|Penggalian| } \\
\text { data|nama|alternative| } \\
\text { definisi|eksaknya|KDD|knowledge| } \\
\text { discovery| } \\
\text { database|analisis|pola|arkeologi|data|pemanenan| } \\
\text { informasi| intelegensia|bisnis }\end{array}$ \\
\hline
\end{tabular}




\begin{tabular}{|l|l|l|}
\hline 5 & http://www.thearling.com & Introduction|Data|Mining|Discovering|hidden|value \\
& /text/dmwhite/dmwhite.ht & | data|warehouse|Data|mining|extraction|hidden \\
& & |predictive|information|large|databases|powerful \\
& |technology |great|potential| help|companies|focus \\
& |important|information| \\
& data|warehouses|Data|mining|tools|predict|future|tre \\
& nds| behaviors|allowing \\
& |businesses|make|proactive|knowledge- \\
& driven|decisions| automated,|prospective|analyses \\
& |offered| data|mining| beyond| analyses| past \\
& |events|provided| retrospective|tools|typical| \\
& decision|support|systems.|Data|mining|tools| \\
& answer|business |questions| traditionally| \\
& time|consuming| resolve. \\
\hline
\end{tabular}

\section{Word Stemming}

Pada tahapan ini berdasarkan kajian teori mengenai preprocessing word stemming, peneliti memfasilitasi penggunaan kata Bahasa inggris dan Indonesia pada teks hasil pencarian,stemming mengilangkan previks pada kata hasil pencarian, berikut word stemming untuk data dari laman https://en.wikipedia.org/wiki/Data_mining, yang telah melewati proses filtration.

Tabel 7. Word Stemming

\begin{tabular}{|l|l|}
\hline Kata & Output \\
\hline Data & Data \\
\hline Mining & mine \\
\hline Data & Data \\
\hline Mining & mine \\
\hline Process & Process \\
\hline practice & practice \\
\hline automatically & Automatic \\
\hline Large & Large \\
\hline Data & Data \\
\hline Sets & Set \\
\hline Involving & Involve \\
\hline
\end{tabular}

\begin{tabular}{|l|l|}
\hline Kata & Output \\
\hline Methods & method \\
\hline Intersection & Intersect \\
\hline Machine & Machine \\
\hline Learning & Learn \\
\hline Statistics & Statistic \\
\hline Database & Database \\
\hline Systems & System \\
\hline interdisciplinary & Interdicipline \\
\hline subfield & subfield \\
\hline computer & computer \\
\hline science & science \\
\hline
\end{tabular}

Pada laman yang berbahasa Indonesia berdasarkan Tabel 1 prefiks dan stop words dihilangkan.

\begin{tabular}{|l|l|}
\hline Kata & Output \\
\hline Penggalian & Gali \\
\hline Data & Data \\
\hline Bahasa & Bahasa \\
\hline Inggris & Inggris \\
\hline Data & Data \\
\hline Mining & Mine \\
\hline Ekstraksi & Ekstrak \\
\hline pola & Pola \\
\hline Data & Data \\
\hline Jumlah & Jumlah \\
\hline Besar & Besar \\
\hline
\end{tabular}

\begin{tabular}{|l|l|}
\hline Kata & Output \\
\hline Dipahami & Paham \\
\hline Berlaku & Laku \\
\hline Data & Data \\
\hline Diprediksi & Prediksi \\
\hline Derajat & Derajat \\
\hline Penggalian & Gali \\
\hline Data & Data \\
\hline nama & Nama \\
\hline Alternative & Alternative \\
\hline Definisi & Definisi \\
\hline Eksaknya & Eksak \\
\hline
\end{tabular}


8. Indexing

\begin{tabular}{|l|l|}
\hline Pola & Pola \\
\hline Dikatakan & Kata \\
\hline Menarik & Tarik \\
\hline Pola & Pola \\
\hline Sepele & Sepele \\
\hline Implisit & Implisit \\
\hline Diketahui & Tahu \\
\hline Berguna & Guna \\
\hline Pola & Pola \\
\hline Disajikan & Saji \\
\hline Haruslah & Harus \\
\hline Mudah & Mudah \\
\hline
\end{tabular}

\begin{tabular}{|l|l|}
\hline KDD & KDD \\
\hline Knowledge & Knowledge \\
\hline Discovery & Discovery \\
\hline database & database \\
\hline analisis & analisis \\
\hline pola & pola \\
\hline Arkeologi & Arkeologi \\
\hline Data & Data \\
\hline Pemanenan & Pemanenan \\
\hline Informasi & Informasi \\
\hline Intelegensia & Intelegensia \\
\hline Bisnis & Bisnis \\
\hline
\end{tabular}

Pada tahapan ini dilakukan skema pembobotan TF-IDF (Term Frequency, Inverse Document Frequency ) dengan menghitung beberapa banyak kata kunci muncul dalam laman web tersebut. Dari sample laman yang ditentukan maka koleksi Dokumen $|\mathrm{C}|=$ 5, jumlah kemunculan term pada dokumen (TF), Nt adalah menunjukan jumlah istilah dalam dokumen $\mathrm{Nt}_{\mathrm{i}}$. Tabel pembobotan laman web berdasarkanTF-IDF, dengan total kata setiap dokumen pada simulasi analisis ini adalah 100 kata.

Tabel 8. Indexing

\begin{tabular}{|c|l|}
\hline $\begin{array}{l}\text { Kode } \\
\text { dokumen }\end{array}$ & Url \\
\hline $\mathrm{d} 1$ & http://searchsqlserver.techtarget.com/definition/data-mining \\
\hline $\mathrm{d} 2$ & https://en.wikipedia.org/wiki/Data mining \\
\hline $\mathrm{d} 3$ & $\begin{array}{l}\text { https://docs.oracle.com/cd/B28359_01/datamine.111/b28129/process. } \\
\text { htm }\end{array}$ \\
\hline $\mathrm{d} 4$ & https://id.wikipedia.org/wiki/Penggalian_data \\
\hline $\mathrm{d} 5$ & http://www.thearling.com/text/dmwhite/dmwhite.htm \\
\hline
\end{tabular}

\begin{tabular}{|c|c|c|c|c|c|c|}
\hline & $\mathrm{tf}=$ jum & $\mathrm{h}$ istilah & $\begin{array}{l}\text { muncul dlr } \\
\text { ata dlm dol }\end{array}$ & $\begin{array}{l}\text { dokumen } \\
\text { umen }\end{array}$ & jumlah total & $\mathrm{N}_{\mathrm{t}}$ \\
\hline $\mathrm{Q}$ & $\mathrm{d} 1$ & $\mathrm{~d} 2$ & $\mathrm{~d} 3$ & $\mathrm{~d} 4$ & $\mathrm{~d} 5$ & \\
\hline data & 0.0050 & 0.0333 & 0.0750 & 0.0333 & 0.0417 & 0.1883 \\
\hline mining & 0.0167 & 0.0167 & 0.0583 & 0.0083 & 0.0417 & 0.1417 \\
\hline
\end{tabular}

\begin{tabular}{|c|c|c|}
\hline$|\mathrm{C}| / \mathrm{N}_{\mathrm{t}}$ & $\mathrm{IDF}=\mathrm{LOG}\left(|\mathrm{C}| / \mathrm{N}_{\mathrm{t}}\right)$ & $\mathrm{IDF}+1$ \\
\hline 26.5522 & -0.7160 & 0.2840 \\
\hline 35.2941 & -0.5315 & 0.4685 \\
\hline
\end{tabular}

\begin{tabular}{|l|r|r|r|r|r|}
\hline & \multicolumn{6}{|c|}{$\mathrm{w}=\mathrm{tf}(\mathrm{IDF}+1)$} \\
\hline Q & $\mathrm{d} 1$ & $\mathrm{~d} 2$ & $\mathrm{~d} 3$ & $\mathrm{~d} 4$ & $\mathrm{~d} 5$ \\
\hline data & 0.0014 & 0.0095 & 0.0213 & 0.0095 & 0.0118 \\
\hline mining & 0.0078 & 0.0078 & 0.0273 & 0.0039 & 0.0195 \\
\hline Total Bobot & $\mathbf{0 . 0 0 9 2}$ & $\mathbf{0 . 0 1 7 3}$ & $\mathbf{0 . 0 4 8 6}$ & $\mathbf{0 . 0 1 3 4}$ & $\mathbf{0 . 0 3 1 4}$ \\
\hline
\end{tabular}




\begin{tabular}{|r|r|r|}
\hline TF Query & IDF +1 & TF*IDF \\
\hline 0.2000 & 0.2840 & 0.056799331 \\
\hline 1.0000 & 0.4685 & 0.468521083 \\
\hline
\end{tabular}

\begin{tabular}{|c|c|c|c|c|}
\hline \multicolumn{5}{|c|}{$\mathrm{SQRT}\left(\mathrm{wd}^{2}\right)$} \\
\hline$|\mathrm{D} 1|$ & $|\mathrm{D} 2|$ & $|\mathrm{D} 3|$ & $|\mathrm{D} 4|$ & $|\mathrm{D} 5|$ \\
\hline 0.0792 & 0.2247 & 0.3371 & 0.2247 & 0.2512 \\
\hline 0.2348 & 0.0551 & 0.1929 & 0.0276 & 0.1378 \\
\hline \multicolumn{5}{|c|}{$\mathrm{SQRT}\left(\mathrm{wq}^{2}\right)$} \\
\hline$|\mathrm{q} 1|$ & $|\mathrm{D} 2|$ & $|\mathrm{D} 3|$ & $|\mathrm{D} 4|$ & $|\mathrm{D} 5|$ \\
\hline 0.1577 & 0.4472 & 0.6708 & 0.4472 & 0.5000 \\
\hline 0.1414 & 0.1414 & 0.2646 & 0.1000 & 0.2236 \\
\hline
\end{tabular}

\begin{tabular}{|c|c|c|c|c|c|}
\hline & $\mathrm{d} 1$ & $\mathrm{~d} 2$ & $\mathrm{~d} 3$ & $\mathrm{~d} 4$ & d5 \\
\hline $\begin{array}{l}\text { Dot } \\
\text { Product }(Q, D)=\end{array}$ & 0.004 & 0.005 & 0.017 & 0.003 & 0.012 \\
\hline $\begin{array}{l}\text { Cosine } \\
\text { Similarity = }\end{array}$ & 0.358 & 0.05 & 0.074 & 0.028 & 0.094 \\
\hline
\end{tabular}

Nilai ambang batas trashhold diambil dari nilai cosine similarity terkecil $=\mathbf{0 . 0 2 8}$

\subsection{Text Mining Discovery Menggunakan Algoritma GARW}

Seperti pada pemaran kajian pustaka mengenai algoritma apriori, untuk menemukan kombinasi item berdasarkan barang yang dibeli oleh pelanggan, dalam studi kasus ini barang yang dibeli dianalogikan sebagai konten yang dicari pada halaman web. Association rule menemukan pola, asosiasi, korelasi yang sering terjadi di antara kumpulan item atau objek dalam database transaksi, database relasional, dan repositori informasi lainnya. Pada kaitan mengenai pencarian di google, terdapat motivasi untuk menemukan bagaimana pengguna mendapatkan informasi yang dibutuhkannya saja tanpa melihat keseluruhan konten dalam website. Sehingga hal tersebut terdapat pola yang dipelajari dari umumnya pengguna melakukan pencarian berdasarkan kategori tertentu.

Sebagai gambaran umum, misalkan pada pencarian google konten yang dicari dari contoh kasus web crawler ini adalah hanya mengenai definisi, metode, latar belakang saja, sehingga hasil pencarian tersebut diharapkan hanya mengenai definisi, metode dan latar belakang saja. Association rule akan mengklasifikasikan konten hasil pencarian google dengan melakukan penambangan teks hanya yang terkait dengan definisi, metode dan latar belakang saja. Untuk Menganalisis Algoritma GARW yaitu harus :

1. Menentukan nilai ambang batas (bobot threshold) seperti pada Tabel pembobotan laman web berdasarkan TF-IDF,

2. ditentukan nilai ambang batas adalah 0.028 , artinya laman yang memiliki nilai ambang batas dibawah 0.028 akan di lewati atau tidak diproses,

3. Menyusun Konten URL berdasarkan nilai ambang batas (bobot threshold)

4. Generate Association rule menggunakan algoritma Apriori, dan Gunakan minimum support dan confidence.

5. Dalam proses Generate Association Rule

a. Scan list index dan temukan semua kata kunci yang memenuhi ambang batas minimum support,

b. Dalam $\mathrm{K}>=2$ ( $\mathrm{K}$ adalah kumpulan kata kunci yang memiliki set k-kata kunci ), kandidat kata kunci $\mathrm{C}_{k}$, dimana nilai $\mathrm{k}$ di hasilkan dari set kata kunci. 
c. Pindai daftar index frekuensi menghitung dari set kata kunci $\mathrm{C}_{\mathrm{k}}$ yang dihasilkan pada langkah b,

d. Bandingkan frekuensi set calon kata kunci dengan minimum support,

e. Set kata kunci k yang memenuhi minimum support

\begin{tabular}{|c|l|l|}
\hline $\begin{array}{c}\text { Kode } \\
\text { dokumen }\end{array}$ & \multicolumn{1}{|c|}{ Konten URL } & \multicolumn{1}{|c|}{ Item yang di Cari } \\
\hline $\mathrm{d} 3$ & $\begin{array}{l}\text { https://docs.oracle.com/cd/B28359_01/datamine } \\
\text {.111/b28129/process.htm }\end{array}$ & Definisi, process \\
\hline $\mathrm{d} 5$ & $\begin{array}{l}\text { http://www.thearling.com/text/dmwhite/dmwhit } \\
\text { e.htm }\end{array}$ & Definisi, architecture \\
\hline $\mathrm{d} 1$ & $\begin{array}{l}\text { http://searchsqlserver.techtarget.com/definition/ } \\
\text { data-mining }\end{array}$ & Definisi, technique \\
\hline $\mathrm{d} 2$ & $\underline{\text { https://en.wikipedia.org/wiki/Data mining }}$ & $\begin{array}{l}\text { Definisi, background, } \\
\text { process }\end{array}$ \\
\hline $\mathrm{d} 4$ & https://id.wikipedia.org/wiki/Penggalian_data & $\begin{array}{l}\text { Definisi, Latar } \\
\text { belakang, Teknik }\end{array}$ \\
\hline
\end{tabular}

Iterasi ke-1

Untuk 1-itemset

\begin{tabular}{|l|l|l|}
\hline \multicolumn{1}{|c|}{ Itemset } & Support Count & \multicolumn{1}{c|}{ Support } \\
\hline Definsi & 5 & $100 \%$ \\
\hline Technique/process & 4 & $80 \%$ \\
\hline Latar belakang / background & 2 & $40 \%$ \\
\hline Arsitektur & 1 & $20 \%$ \\
\hline
\end{tabular}

dapatkan k-itemset dari support yang memenuhi minimum support, kemudian pilih k-itemset sebagai pola frequent tinggi, ditentukan minimum support adalah 1.

\begin{tabular}{|l|l|l|}
\hline \multicolumn{1}{|c|}{ Itemset } & \multicolumn{1}{c|}{ Support Count } & \multicolumn{1}{c|}{ Support } \\
\hline Definsi & 5 & $100 \%$ \\
\hline Technique/process & 4 & $80 \%$ \\
\hline Latar belakang / background & 2 & $40 \%$ \\
\hline
\end{tabular}

\section{Iterasi ke-2}

Table C2 kombinasi dari k-itemset

\begin{tabular}{|l|c|c|}
\hline \multicolumn{1}{|c|}{ Itemset } & Support Count & Support \\
\hline Definsi, Technique/process, & 4 & $80 \%$ \\
\hline $\begin{array}{l}\text { Definisi, Latar belakang / } \\
\text { background }\end{array}$ & 2 & $40 \%$ \\
\hline $\begin{array}{l}\text { Technique/process, Latar belakang / } \\
\text { background }\end{array}$ & 1 & $20 \%$ \\
\hline
\end{tabular}

Berikut table Pola frequent tinggi diatas minimum support untuk 2-itemset adalah (F2).

\begin{tabular}{|c|c|c|}
\hline Itemset & Support Count & Support \\
\hline Definsi, Technique/process & 4 & $80 \%$ \\
\hline $\begin{array}{c}\text { Definisi, Latar belakang / } \\
\text { background }\end{array}$ & 2 & $40 \%$ \\
\hline
\end{tabular}

\section{Iterasi ke-3}




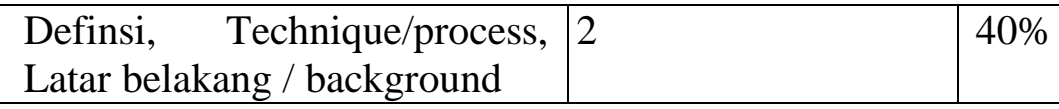

Proses berhenti pada iterasi ke 3, pola frequent tinggi yang ditemukan adalah "Definsi, Technique/process, Latar belakang / background"

\section{PENUTUP}

Association rule menemukan pola, asosiasi, korelasi yang sering terjadi di antara kumpulan item atau objek dalam database transaksi, database relasional, dan repositori informasi lainnya. Penentuan bobot threshold menggunakan cosine similarity ini berdasarkan kesamaan istilah antara query dengan dokumen konten web (Bathla \& Jindal, 2011). Keuntungan dari pendekatan ini adalah bahwa area pencarian menjadi sangat kecil sehingga waktu tunggu pengguna untuk mendapatkan jawaban permintaan berkurang untuk sebagian besar, dan diharapkan dapat mengurangi waktu pencarian informasi dalam memberikan rekomendasi hasil pencarian yang diinginkan berdasarkan pola, asosiasi, korelasi pencarian.

Dengan bobot threshold 0.028 pada simulasi mengeliminasi dokumen web yang berada pada bobot threshold $<=0.028$ sehingga proses melakukan Generate Association Rule menjadi lebih ringan. Adapun dari sudut pandang konten yang dievaluasi melibatkan multi Bahasa Indonesia dan inggris, hal tersebut menambah variatif konten informasi yang didapatkan. Adapun kekurangan dari algoritma ini adalah hasil input pada konten yang akan di evaluasi perlu di lengkapi dengan efisiensi akses data, jika input data yang diberikan adalah lebih dari 1000 record, maka mekanisme akses perlu di pertimbangkan. Mekanisme akses saat ini adalah dengan memberi limit berdasarkan kelipatan tertentu, Namun penulis perlu menyempurnakan kondisi ini agar dibuatkan lebih dinamis namun efisien sehingga baik dengan jumlah record < 100 atau konten > 1000 record memiliki load data yang stabil.

Pada kajian ini foKus pada bagaimana melakukan penambangan teks terhadap dokumen semi terstruktur html dengan mengambil konten yang diperlukan dan kemudian dilakukan penambangan teks untuk menemukan pola. Adapun dokumen yang tidak terstruktur seperti dokumen pdf, doc yang merupakan hasil pencarian menjadi open issue untuk penelitian selanjutnya.

\section{DAFTAR PUSTAKA}

Bathla, G., \& Jindal, R. (2011). Similarity Measures of Research Papers and Patents. International Journal of Computer Applications, 10.

Bhujade, V., \& Janwe, N. (2011). Knowledge Discovery in Text Mining Technique Using Association Rules Extraction. International Conference on Computational Intelligence and Communication Systems, 498-502.

Christopher Olston, M. N. (2010). Web Crawling. Foundations and Trends in Information Retrieval, 4(3), 176.

Janwe, V. B. (2011). Knowledge Discovery in Text Mining Technique Using Association Rules Extraction. International Conference on Computational Intelligence and Communication Systems, 498-502.

Kulkarni, M. K. (2016). KNowledge Discovery in Text Mining using Association Role Extraction. International Journal of Computer Application , 143(12), 31. 
Naithani, A. K. (2016). A Comprehensive Study of Text Mining Approach . International Journal of Computer Science and Networking Security, 16(2), 69.

Najork, M., \& Heydon, A. (2001). High Performance Web Crawling . California: Compac System Research Center.

R, J., \& Vijayarani, D. S. (2016). Text Mining Reserach: A Survey. International Journal of Innovative Research in Computer and Communication Engineering, 6544.

R. Talib, M. K. (2016). Text Mining : Techniques, Applications and Issues. International Journal of Advanced Computer Science and Applications, 414.

Sanger, R. F. (2007). The Text Mining Handbook Advanced Approaches in Analyzing Unstructured Data. Cambrige: Cambrige University.

Tala, F. (2003). A Study of Stemming Effects on Information Retrieval in Bahasa Indonesia. Amsterdam: Institute for Logic, Language and Computation The Netherlands. 